\title{
A história da cidade como instrumento de projeto e intervenção: o Núcleo Colonial de Ribeirão Pires, um estudo de caso.
}

Pedro Murilo Gonçalves de Freitas *

\section{Resumo}

Este artigo trata do desenvolvimento urbano do vale central do município de Ribeirão Pires a partir da instalação da estação ferroviária de mesmo nome da São Paulo Railway, associada a seus Núcleos Coloniais "Sede", "Colônia" e "Pilar", no final do século XIX, pelo Governo Imperial. Foi analisada a formação histórica da área compatibilizando a documentação coletada a estudos mais profundos dos modos de permanência do desenho urbano municipal. Esta pesquisa buscou constantes críticas sobre parâmetros de leitura das cidades contemporâneas, visto que a aparente uniformidade de sua paisagem tem dificultado percepções históricas coerentes pelos seus habitantes, promovendo-se a contínua degradação de seu patrimônio cultural. Discute-se a necessidade da valorização da memória e da história local como formas de ação sobre as cidades em políticas públicas culturais, e como parâmetros a novos projetos de intervenção urbana.

Palavras-chave: Núcleos coloniais. Ribeirão Pires. Patrimônio cultural.

The city history as an instrument of project and intervention: The Ribeirão Pires Colonial Nucleon, a case study.

\begin{abstract}
This article presents the urban development of the central valley of Ribeirão Pires city started with the installation of the same name station on the "São Paulo Railway" associated to its colonization nucleons called "Sede", "Colônia" and "Pilar" in the end of XIX century by the Imperial Government. It was analyzed the area's history formation joining the collected documentation to a more deeper analysis of the actual city's design. The research aimed a constant review over the historical reading parameters of contemporary cities, because the apparent uniformity of its landscape has turned difficult a coherent perception of its history by its inhabitants, promoting
\end{abstract}


the continuous degradation of its cultural heritage. This work discuss the need of the valorization of memory and local history as a form of cultural public politics and as parameters of new projects of public urban intervention.

Key-words: Colonial nucleons. Ribeirão Pires. Cultural heritage

\section{Introdução}

Ribeirão Pires é um município de $107 \mathrm{~km}^{2}$, situado na porção sudeste da Grande São Paulo, denominada Grande ABC. Sua área central caracteriza-se pela presença de um vale no qual se instalou a estação ferroviária de "Ribeirão Pires", na antiga São Paulo Railway, conectada a três núcleos coloniais de imigrantes denominados "Sede", "Colônia" e "Pilar", no final do século XIX.

Essa condição determinou o princípio inegável de sua evolução urbana, e a clara noção de que a área esteve integrada a um sistema lógico regional de exploração econômica. Tratava-se de criar condições para suprir as demandas de crescimento da metrópole paulista com produtos advindos de uma pré-industrialização e de uma agricultura de subsistência, ambos com o apoio do trabalho imigrante e o estímulo de políticas públicas de colonização do período. Em seguida, o espaço da cidade se desenvolveu através das lógicas urbanas do final do século XIX e primeira metade do século XX, estabelecendo-se, na atividade cotidiana de seus ocupantes, a atribuição natural de um valor urbano, um lugar denominado "Ribeirão Pires", situado nesse vale.

Hoje, porém, gradualmente transformada a partir da segunda metade do século XX, e de uma paisagem já modernizada e integrada completamente à dinâmica metropolitana, tem-se atribuído à história de formação do município um único ícone arquitetônico: a Igreja do Pilar. Tombada pelo Condephaat, em 1975, por se vincular às noções de antiguidade e passado dos tempos do Brasil Colônia que guiou a eleição do patrimônio no país no período, a Igreja do Pilar era uma construção em taipa, e passagem, no século XVIII, entre a Vila de Pilar (atual Mauá) e a região do 
Vale do Paraíba, situando-se hoje no território municipal de Ribeirão Pires, a cerca de 4 quilômetros de sua área central.

Por caracterizar tanto o que a cidade podia oferecer de "mais antigo", e ao mesmo tempo "glorioso", a partir de uma memória construída num mito de origem desde os anos de 1950, sua valorização excessiva e tombamento na década de 1970 produziu, ao longo dos anos, o perverso efeito de negação de valor da cidade que se implantou no vale. Soma-se a isso o fato de que a área central (assim como todo o município), por ter sido situada na área de aplicação da lei de proteção aos mananciais nos mesmos anos de 1970, passou a apresentar poucos atrativos à diversificação urbana, visto que a referida lei nunca apresentou alternativas de gestão aos territórios incidentes (algo que só viria a ocorrer nos anos de 1990).

Em função desse cenário, o centro do município de Ribeirão Pires gradualmente foi alvo de um processo de saturação. Ao mesmo tempo, seu núcleo histórico tornou-se uma área fortemente desgastada devido à intensificação do fenômeno de dispersão, nas décadas seguintes, em toda a Grande São Paulo. O foco simbólico do vale como forma de contato com a região metropolitana na mesma estação, quehoje se integra à linha $D$ de trens metropolitanos da CPTM, tem evidenciado o conflito entre as recentes demandas municipais e a permanência dos indícios históricos de formação urbana na paisagem que faz referência à identidade da cidade.

Desse modo, os governos municipais das últimas décadas têm trabalhado no sentido de evidenciar essas características que se conservaram, utilizando-se do artifício do turismo como meio de divulgar seu patrimônio arquitetônico e urbanístico, aliado a diversas intervenções que conciliem essas novas demandas.

Porém, é notável a falta de critérios para a consolidação e aplicação dessas políticas - ainda que legítimas - de reordenação espacial e, principalmente, de diversificação de fontes financeiras. As tentativas de ação das políticas públicas urbanas não têm sido aplicadas com efetividade no que tange à preservação do seu patrimônio cultural, embora estejam previstas tanto em leis municipais, como no último plano diretor, elaborado em 2003. 
O turismo municipal, ainda que seja interpretado como a saída contemporânea para um problema gerado pela aplicação de uma legislação excessivamente restritiva nos anos de 1970, tem produzido o efeito paradoxal de convalidar as antigas políticas de criação de identidades baseadas nos mitos de origem. Tal noção choca-se diretamente com o espaço da cidade que ainda é vivido pelos seus habitantes, constituído de ruas e construções de diversas épocas sobrepostas, e transformadas ao longo do século XX. A cidade histórica não é apenas o entorno da Igreja do Pilar.

Ao mesmo tempo, o que se pode visitar num ambiente urbano cuja paisagem é uma amálgama histórica, habilmente dissonante em relação à sua origem? Ainda que a cidade apresente seus indícios físicos, a predominância do imaginário coletivo sobre uma origem gloriosa do município permanece sendo valorizada pelo simples fato de que é a saída histórica mais conveniente às políticas públicas. Portanto, a cidade, seus visitantes (e, principalmente, seus governantes) passam, no mínimo, por um problema de percepção.

Este artigo apresenta, utilizando dados documentais, cartográficos e iconográficos, processos de construção urbana do vale central do município de Ribeirão Pires, cujos traços físicos ainda permanecem nos dias de hoje, mas que se encontram ignorados em razão das diversas transformações no século XX.

Sobretudo, trata-se de trazer o tema da história da cidade à reflexão projetual. Hoje, é notável a desvinculação da produção da cidade no presente àquela construída no passado, tendo o poder público eximido-se de responsabilidade sobre boa parte das ações coletivas no espaço urbano central das cidades brasileiras. Se é preciso conhecer para preservar, é mais ainda preciso conhecer para intervir.

Conheçamos, portanto, neste estudo de caso, Ribeirão Pires.

2 Os antecedentes históricos: a regulação fundiária, a construção do sistema ferroviário e os primeiros núcleos coloniais paulistas do Império 


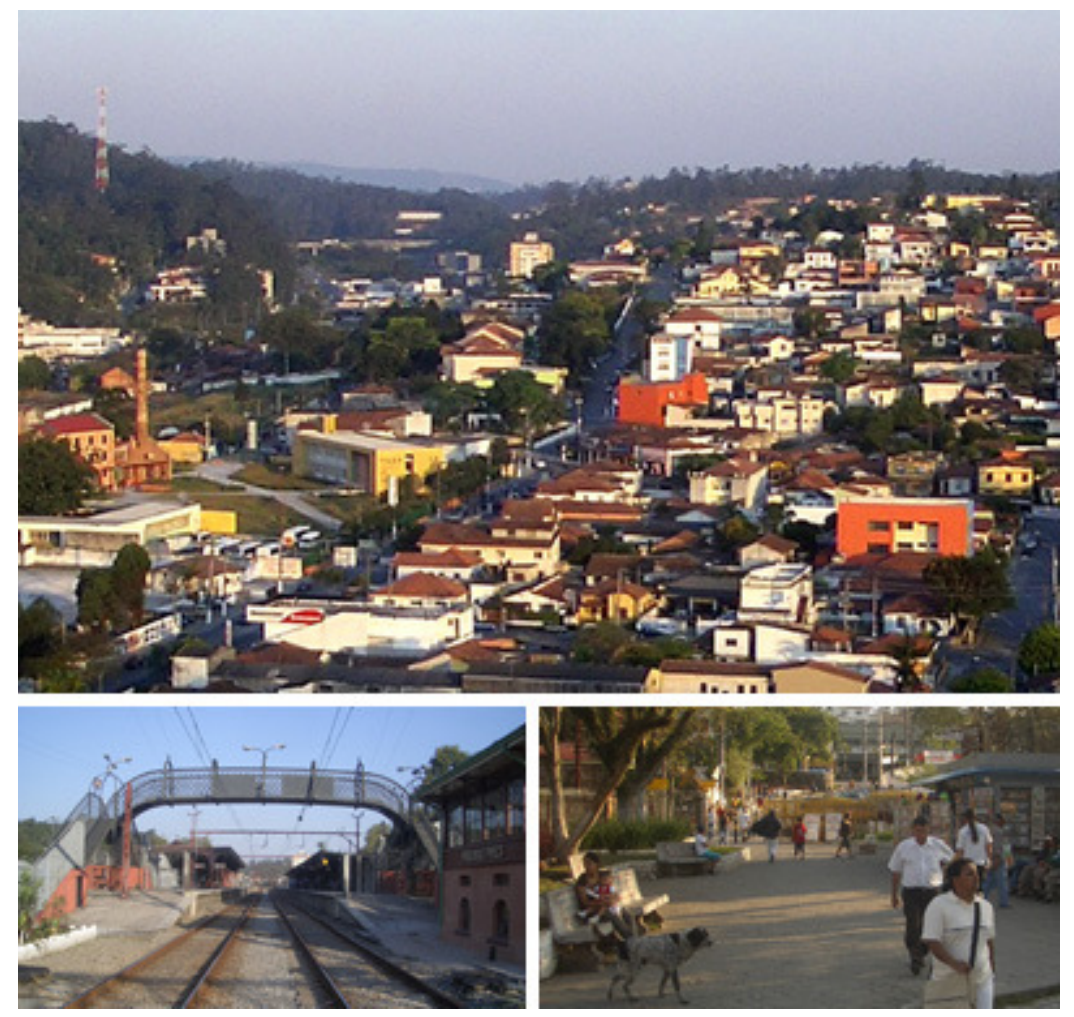

FIGURA 1 - Ao centro, paisagem de Ribeirão Pires com a linha férrea à esquerda, e o bairro chamado "Núcleo Colonial" à direita. Abaixo, à esquerda, vista do conjunto ferroviário a partir da passagem de nível. Abaixo, à direita, aspecto do conjunto ferroviário na passagem de nível. Fotos do autor, 2006.

A formação urbana do vale da atual área central de Ribeirão Pires é o resultado direto das experiências do Governo Imperial nas políticas de substituição do trabalho escravo pelo imigrante, e da implantação das estradas de ferro em todo o país. Não há qualquer referência à ocupação do espaço central da atual Ribeirão Pires anterior à própria linha.

A área mereceu suas primeiras intervenções no traçado técnico que se implantou sobre esse vale entre 1864 e 1866, com a inauguração da segunda etapa de construção do caminho da ferrovia (KÜHL, 1998, p. 131). Sem ainda a existência de uma estação, o contato do sistema ferroviário com o próprio vale é somente o de passagem.

Segundo Fábio Cyrino, o traçado da linha até São Paulo exigiu grandes cortes em função de sua geologia (em xisto e granito). O trecho da serra até as proximidades da nascente do Rio Tamanduateí, que a linha passou a margear - de pequenos morros e riachos - mereceu intervenções de pouca magnitude, totalizando "cento e doze pequenas pontes e arcos com aberturas máximas de vãos de seis metros" (CYRINO, 2000, p. 80). Vencidas as escarpas da Serra do Mar em planos inclinados e atingindo São Paulo a partir de Santos, a ferrovia, em consolidação neste trecho, 
apresentava poucas estações - Alto da Serra (em Paranapiacaba), Rio Grande da Serra (uma antiga aglomeração de passagem situada no contato do Rio Grande com um caminho antigo, a Mogi das Cruzes) e São Bernardo (no ponto da atual Santo André) -, demonstrando que a empresa ferroviária precisava estabelecer seus pontos estratégicos de funcionamento dentro do claro objetivo de escoar a produção do café do interior paulista (as estações terminais, algumas estações importantes, o sistema de funiculares e a linha em si). Nesse contexto, o vale da atual Ribeirão Pires era apenas um espaço de passagem, sem evidência de ocupação efetiva, sendo essas terras, até então, em grande parte devolutas.

Desde 1822, com o processo de Independência, o Governo Imperial começou a dar os primeiros passos para regulamentar a herança fundiária do período colonial, baseada na aquisição de terras por posse ou por sesmaria, método considerado "atrasado" para o desenvolvimento do Império. É de se notar, no período, a dificuldade do governo de manter a unidade do território nacional, dada a sua fragilidade. Diversos projetos de lei foram propostos, mas a questão sempre esbarrava em interesses locais de grandes posseiros que, cada vez mais, incorporavam terras às suas propriedades, sem cultivá-las.

Em 1850, finalmente, a Lei de Terras (1) definiu um novo padrão de ocupação das áreas rurais no país. É somente com essa lei que a situação anterior foi extinta, resultado direto da consolidação do poder do Governo Imperial, do abafamento das revoltas regionais e do fim do tráfico negreiro, legitimando a posse com cultivo. Ao considerar como "devoluta" - termo de origem colonial - toda a terra que se encontrasse sem qualquer tipo de beneficiamento, estabeleceu os parâmetros para a introdução gradual do trabalho imigrante nessas terras. (2)

No entanto, agregando-Ihes valor, na medida em que permitia posseiros e sesmeiros adquirirem títulos de propriedade e a possibilidade de comercializá-los (3), essa lei favoreceu em todo o país, no período anterior à sua promulgação, a posse indiscriminada de terras. Ainda que inocuamente, pequenos beneficiamentos eram criados pelos posseiros para que não fossem consideradas devolutas. A Lei, embora objetivasse a regulação fundiária e o estímulo à introdução do trabalho assalariado imigrante para suprir a eminente escassez do trabalho escravo, procurando tornar 
disponíveis grandes áreas para a localização das colônias, pecou por permitir também um novo tipo de atividade, o da especulação fundiária, já que a terra, como nova mercadoria, seria capaz de gerar lucro, nos parâmetros da nova economia industrial. Era a pressão que o capital estrangeiro - principalmente o inglês - fazia cumprir. Somando-se a isso, a implantação gradual da ferrovia no país condicionou a valorização de grande parte das terras, seja pela noção da possibilidade de "conexão imediata com o mundo", evidente, seja pelo novo conceito que acabara de se introduzir na dinâmica econômica do país, o da "expectativa urbana", estimulante ainda mais dos processos de especulação.

Por essas razões, em todo o Império, até o ano de 1874, o governo ainda não havia conseguido estabelecer um cadastro completo do estado das terras devolutas para poder executar a sua política de colonização. Mesmo já tendo começado a trabalhar diversas comissões de medição em todas as províncias, conforme descreve o relatório do Ministério da Agricultura, em 1874, elaborado pelo Ministro José Fernandes da Costa Pereira Junior em sua seção "Terras Públicas", a lentidão dos serviços tornava cada vez mais sem efeito a referida lei:

São decorridos mais de vinte annos depois que foi posta em execução a lei n. 601 de 18 de setembro de 1850.

Entretanto, não estando ainda discriminadas as terras do dominio particular das do publico, impossivel é determinar a extensão de umas e de outras.

Em meu conceito, não deve continuar semelhante estado de cousas, o qual, alem de offerecer em relação a grande numero de possuidores todas as desvantagens inherentes à incerteza da propriedade, prejudica sensivelmente o direito do Estado que, nem sempre dispondo de meios efficazes para impedir as usurpações, corre o risco de ver diminuido seu patrimônio territorial.

Se interesses de ordem publica não aconselhão a applicação rigorosa da lei aos posseiros, sesmeiros e concessionarios, que ainda não fizerão legitimar ou revalidar suas terras, oppoem-se também a que os terrenos devolutos continuem a ser objecto de especulações por parte de intrusos, que, prevalecendo-se da inefficacia dos meios coercitivos, vão usurpando o que é de propriedade do Estado.

Nomeando commissões de engenheiros para em diversos pontos do Império providenciarem acerca da legitimação de posses e revalidação de sesmarias e outras concessões; promovendo a medição das terras possuídas por individuos pobres; e estabelecendo na venda das occupadas por agricultores laboriosos preferencia para os occupantes, mostra o Governo que não se tem descuidado de dar fiel execução á citada lei 
de 1850.

Cumpre, porém, ponderar que taes providencias não produziram ainda todos os effeitos que se esperavão.

$[\ldots]$

As sucessivas prorogações do prazo fixado aos posseiros, e aos sesmeiros e outros concessionarios para legitimação das posses e revalidação das sesmarias e concessões geraes e provinciais tem-Ihes feito acreditar que nunca serão privados das terras pela imposição do commisso, em que incorrão, nos termos da citada lei. (RELATÓRIOS, 1874, p. 240-1)

Ao mesmo tempo, algumas tentativas de colonizações promovidas por grandes proprietários de terras, por se localizarem em áreas muito afastadas de alguma vida econômica e os vincularem necessariamente à produção dessas fazendas, condicionaram o fracasso de algumas colônias agrícolas, que redundou em má propaganda nos países europeus, imediatamente combatida para não interromper o fluxo imigratório. A temática do relatório prossegue na seção "Imigração e Colonisação":

[...] Os núcleos coloniaes, que devião constituir outros tantos focos de atracção para os immigrantes europeos, não forão assentados nos lugares onde mais facil seria a prosperidade de seus povoadores. Em vez de serem estabelecidos nas proximidades das cidades e de portos em que houvesse mercado para os generos de sua producção, fundaram-n'os em lugares geralmente notaveis pela uberdade das terras e exccellencia do clima, mas verdadeiros desertos, - nas asperezas do sertão bravio, - em remotas paragens, algumas das quaes nem ao menos tinham sido exploradas pelo sertanista nacional. D'aqui é fácil colligir que difficuldades encontram os primeiros povoadores d'esses núcleos, e que sacrifícios têm custado ao Estado o melhoramento d'elles, conseguindo-se á força de trabalho e de dispêndios o que fôra idéa salutar, mas, com menos acerto realizada, dos primeiros tempos em que se cuidou seriamente do serviço de colonisação. A iniciativa particular, que logo encontrou, como a acção do Governo, sérios embaraços na propaganda que, com o fundamento de infortunios de immigrantes pela maior parte avessos ao trabalho, levantou-se contra a immigração para o Brazil nos paizes onde encontramos maior contingente, esmoreceu bem depressa. (RELATÓRIOS, 1874, p. 248-9).

Ao ser criada, em 1876 (4), a "Inspetoria Geral de Terras e Colonisação", órgão do Ministério da Agricultura para promover a colonização no território brasileiro, vinculou-se ao sistema produtivo nacional e especialmente ao sistema ferroviário em implantação, dada a importância estratégica do assunto para o desenvolvimento da 
economia do Império. Centralizando a questão na esfera pública nacional, às províncias caberia apenas o cumprimento das diretrizes estabelecidas no Rio de Janeiro.

Sobre os trabalhos em São Paulo, Walter Pires aponta o relatório de descrição e avaliação de terras elaborado por Nicoláo de Athougia, na margem esquerda do Rio Tietê, em 1874, que resultou na implantação dos núcleos coloniais da Glória, Santanna, São Bernardo e São Caetano, em 1877, os primeiros núcleos paulistas (PIRES, 2003, p. 31-35). Ainda que se detivesse na análise do núcleo da Glória, proposta de seu trabalho, Pires identifica os parâmetros que determinaram a implantação desses núcleos. Em princípio, a qualidade da terra, não apenas no que se refere às condições da terra em si, mas à sua possibilidade de fácil conexão urbana, como já havia sido apontado como essencial, ainda que houvesse terras mais afastadas com melhores condições de plantio; em seguida, tendo em vista a então escassez de terras devolutas dada a situação instalada, a "qualidade" do proprietário. Não sendo o próprio Estado, este encontra nas extensas propriedades dos beneditinos em São Bernardo e São Caetano um ótimo custo-benefício pelo desinteresse nas terras que possuíam.

Representativos, porém, de uma fase transitória do sistema de transporte, esses núcleos ainda não se vinculam totalmente ao sistema ferroviário. Pelo contrário, os territórios em que se implantaram mantiveram-se bastante próximos de caminhos antigos e conectados com alguma distância do traçado da ferrovia em formação. As distâncias de São Bernardo (6 km da estação de mesmo nome), e Santanna (4,5 km da estação da Luz), revelam essa escolha. São Caetano é, porém, a exceção, em que ocorre a coincidência do traçado da linha sobre a fazenda dos beneditinos. No entanto, do mesmo modo que São Bernardo, é um território que não deixa de se influenciar também pela importância remanescente da estrada do Vergueiro e do antigo Caminho Mar (5).

Gradualmente, a implantação do sistema ferroviário fundamentou a escolha das terras nas quais foram instalados os novos núcleos coloniais. De fato, a aproximação é cada vez mais desejada, assim como a solução do processo de especulação que o Império visivelmente passou a enfrentar. Essa aproximação se 
traduzirá num novo padrão de ocupação, menos vinculado a caminhos préexistentes e cada vez mais integrantes (e até dependentes) do novo sistema. Esse é um processo que será discutido no item a seguir, pois a transformação do vale da atual Ribeirão Pires é exemplar.

\section{0 núcleo colonial de Ribeirão Pires: a ampliação e modernização das estações da linha, dos núcleos, e os efeitos da transição do regime}

Devido ao sucesso do sistema, logo surge naturalmente a necessidade de ampliá-lo. Nos anos de 1880 iniciaram-se as obras de duplicação da linha da "São Paulo Railway". Esses trabalhos foram estimulados pelos lucros e benefícios advindos do contrato de construção e concessão pelo Governo Imperial, pela consolidação de sua vinculação com a economia cafeeira através dos diversos ramais com outras companhias no interior do Estado (construídos segundo os interesses dos próprios cafeicultores), e pelo crescimento urbano em São Paulo, que promoveu a expansão do cultivo de área agrícola de subsistência (CYRINO, 2000, p. 98).

Numa primeira etapa, ampliaram-se os pontos de parada na rede para o trânsito de passageiros e a implantação de novas colônias, instalando-se na linha novas, porém ainda precárias, estações. $\mathrm{Na}$ etapa seguinte, já no período republicano, todas as estações foram modernizadas, sendo construídas novas edificações.

No que se refere ao modo de introdução de colonos nas áreas demarcadas, segundo Eduardo Pereira, no trabalho em que procurou identificar a memória dos imigrantes do Núcleo "Barão de Jundiahy", os núcleos coloniais do período apresentavam uma lógica comum e aparentemente simples para fixação à terra, reproduzindo, em pequenas propriedades de lotes urbanos e rurais, modelos de ocupação que buscassem se aproximar das terras de origem desses colonos italianos, principalmente (PEREIRA, 1988, p. 25-27).

Os imigrantes que iriam às colônias não permaneciam nas hospedarias. Eram imediatamente encaminhados às suas destinações, onde eram recebidos e abrigados num barracão. Nos casos, em que já tivessem sido realizados os trabalhos de demarcação dos lotes coloniais rurais, eram encaminhados a estes, sendo que, no barracão, ao oficial, faziam o pedido do título provisório do lote, 
denominado "Designação de Lote de Terras". Tal título determinava obrigações, prazos, pagamentos e sanções. Incluíam-se nas obrigações a necessidade de o colono - lavrador e casado - estabelecer uma lavoura e construir uma casa em no máximo seis meses. Estaria a cargo do governo o compromisso de oferecer materiais para a construção da casa e instrumentos, nem sempre suficientes a todos. Atribuía-se a possibilidade da perda do título provisório de propriedade e das benfeitorias até então realizadas se se esgotasse o prazo mínimo fixado, ou não se desse a quitação das dívidas. Ao ser considerado vacante o lote era novamente posto a venda em hasta pública. Esse procedimento de ocupação se daria até a decretação da emancipação do núcleo.

A lógica da ocupação dos lotes urbanos era a mesma, excetuando-se obviamente o trabalho agrícola e com a diferença de que estes estavam destinados, ou a colonos que já possuíam lotes na colônia rural, ou àqueles colonos que poderiam oferecer algum serviço de artesania ou atividade industrial rural.

Como parte desses projetos urbanos vinculados à política de colonização da primeira etapa é inaugurada a estação de Ribeirão Pires, em $1^{\circ}$ de março de 1885 , sendo que em 1884 já eram apresentados desenhos para a implantação de um núcleo urbano - dito também "Sede de Ribeirão Pires" - e dois núcleos rurais "Colônia" e "Pilar" - após o levantamento das terras devolutas na região (CYRINO, 2000, p. 98). O Relatório de Abril de 1888, apresentado pelo Presidente da Província Dr. Rodrigues Alves ao seu vice, na seção "Comissão de Terras e Colonisação" sob a denominação "Novo Núcleo", anuncia a efetiva implantação, em 1887, do primeiro núcleo rural - localizado no atual Bairro da Colônia -, e dá outras providências para a implantação do núcleo sede, onde já se encontra o barracão de recepção dos imigrantes:

Foi recentemente iniciada a fundação de um novo núcleo, em terras devolutas, á margem da estrada de ferro de Santos a Jundiahy, e contíguo a estação do Ribeirão Pires.

Em barracão alli construído acham-se já alojados 154 colonos.

A algumas dessas famílias tem sido distribuídos lotes para o seu estabelecimento definitivo. Foram já projectados os indispensaveis melhoramentos á formação da Séde Colonial, achando-se em andamento os trabalhos preparatorios de viação, abertura de ruas e lotes destinados ás edificações urbanas. (RELATÓRIOS, 1888, p. 59) 
Embora sucinto, o relatório indica, nas despesas da referida Comissão, que o projeto da sede urbana está sendo executado sobre terras cedidas por D. Maria Florencia Rodrigues (RELATÓRIOS, 1888, p. 54).

Integrado a um sistema de ocupação que se vinculava cada vez mais à ampliação não só da "São Paulo Railway", como da ferrovia e da economia cafeeira em toda a província, nota-se no relatório a preocupação da descrição do estado de outras colônias similares, como o já citado Núcleo Barão de Jundiahy (1887). Outros núcleos foram implantados no período, mas vinculados a outros sistemas de transporte, tais como: o núcleo Senador Antonio Prado (1887), em Ribeirão Preto, à margem da estrada de ferro Mogyana; o núcleo Pariquera-Assu (1887), em Iguape, próximo ao porto de mesmo nome; e o núcleo Conselheiro Rodrigo Silva, em Porto Feliz, à margem da estrada de ferro Sorocabana. Além desses, há referência aos núcleos de Cannas (em Lorena), Boa Vista (em Jacareí), Sabaúna (em Mogi das Cruzes) e Quiririm (em Taubaté), às margens da ferrovia D. Pedro I, no Vale do Paraíba, ainda não implantados mas com demarcação autorizada (RELATÓRIOS, 1888, Anexo 5, p. 44).

No fim do mesmo ano, o relatório do Ministério da Agricultura aponta a fundação do Núcleo de Ribeirão Pires, e dá detalhes quanto à sua possível expansão, dada a sua ocupação massiva por parte dos imigrantes:

Em terras devolutas, com área de $5.626 .100 \mathrm{~m}^{2}, 00$, foi este núcleo fundado em fevereiro do anno proximo passado.

Acham-se medidos 28 lotes rústicos e projectados 70 urbanos.

Acha-se situado na estação da estrada de ferro de Santos a Jundiahy, a 33 kilometros da capital.

As terras são cobertas de boas mattas e bem reputadas quanto á sua fertilidade.

Os colonos estabelecidos acham-se satisfeitos e muito animados com as promessas das suas primeiras culturas.

Póde este núcleo ser augmentado, para o que já se acha discriminada a área de 6.042.390 $\mathrm{m}^{2}, 00$ de terras devolutas adjacentes. (RELATÓRIOS, 1888, Anexo 5, p. 43) 
As plantas que documentam tais projetos estão disponíveis no Centro de Apoio Técnico ao Patrimônio (CATP), na Prefeitura Municipal, e foram aqui reproduzidas. Uma cópia heliográfica, sem data, da "Planta da sede do Núcleo Ribeirão Pires", à escala 1:2500, copiada em 1914 do original elaborado em 21 de Agosto de 1890, pelo agrimensor Antônio Raphael de Almeida, já apresenta os logradouros renomeados segundo os padrões republicanos. Outra, sem data e sem assinatura, provavelmente um levantamento posterior, relaciona os três núcleos coloniais demarcados, lotes cedidos e caminhos construídos, à escala 1:10000.
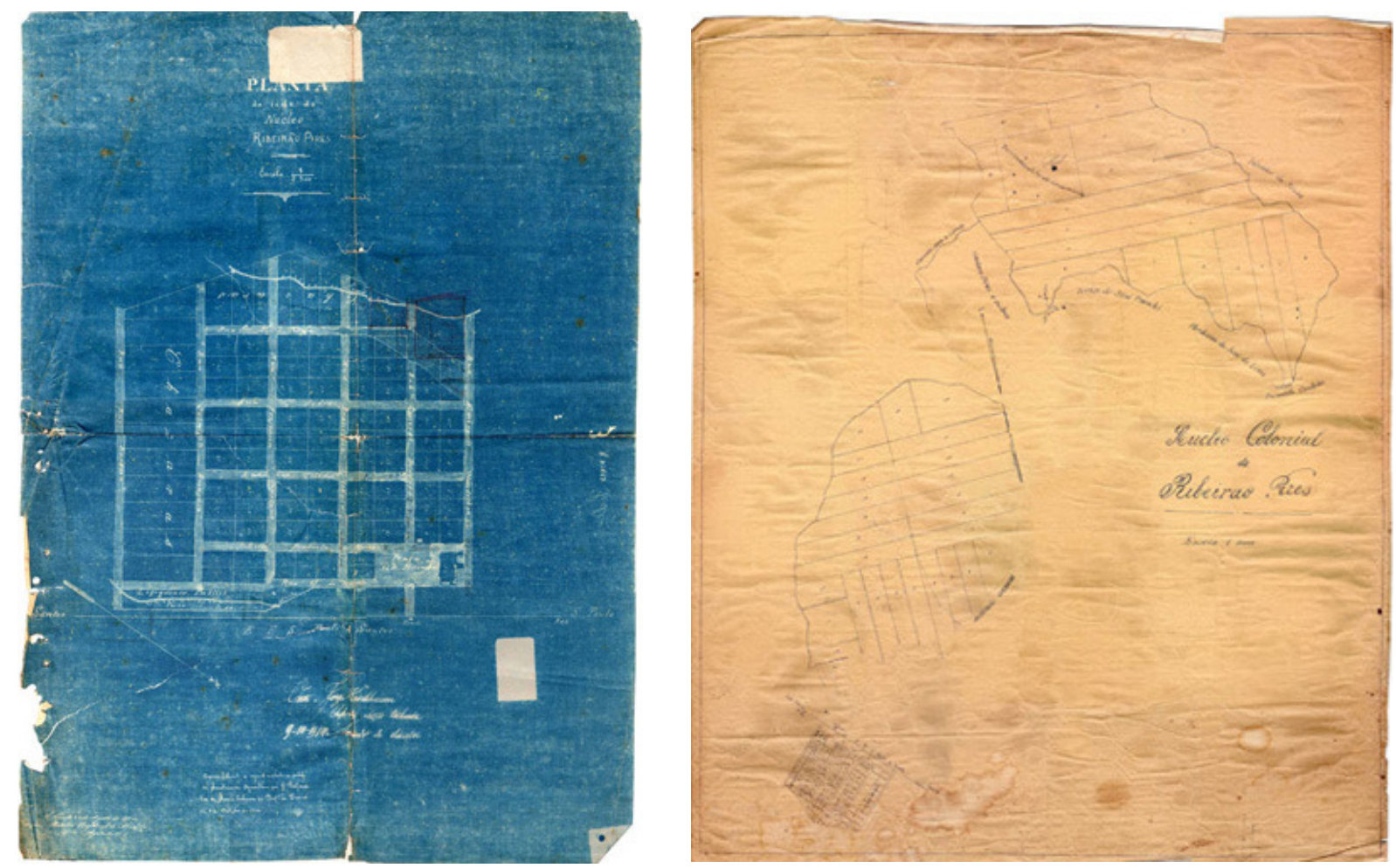

FIGURA 2 - À esquerda, "Planta da sede do Núcleo Ribeirão Pires", à escala 1/2500. Cópia heliográfica antiga, apresentando algumas inscrições no documento. Tamanho original: 64 x 45 cm. À direita, planta do "Núcleo Colonial de Ribeirão Pires", à escala 1:10000. Tamanho original: $65 \times 53 \mathrm{~cm}$. Fonte: CATP/PMETRP. 


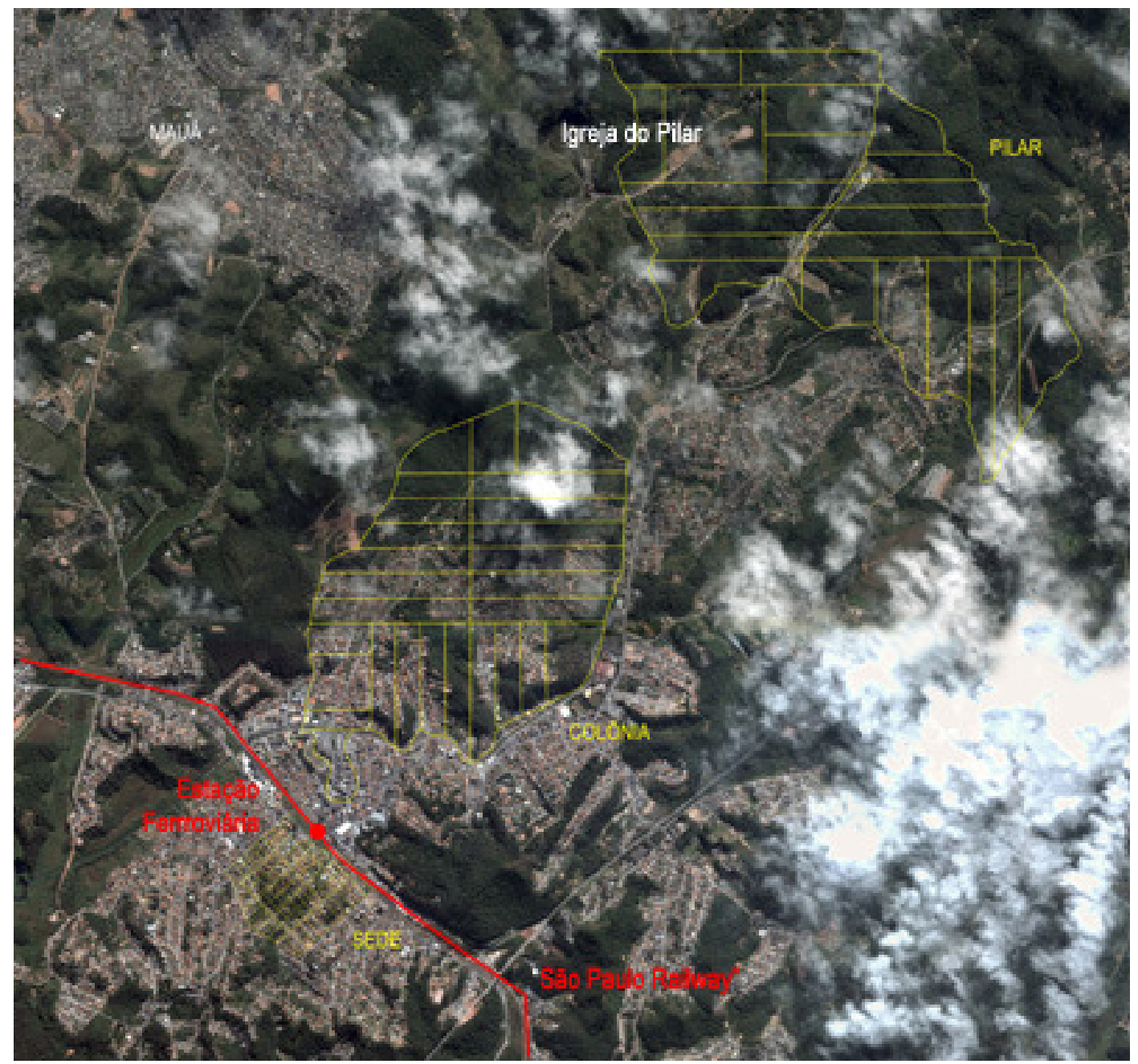

FIGURA 3 - Delimitação dos núcleos coloniais sobre imagem de satélite atual. Nota-se a mancha urbana totalmente integrada ao núcleo "Sede", parcialmente integrada ao núcleo "Colônia", e praticamente inexistente no núcleo "Pilar". Fonte: "Núcleo Colonial de Ribeirão Pires", s.d., e imagens de satélite Google Earth, Digital Globe, 2007.

A análise desses dois documentos nos permite deduzir os métodos de demarcação das colônias no Império. Relacionados às correspodências da "Comissão de Colonisação" disponíveis no Arquivo do Estado (6), é possível inferir sobre os trabalhos de construção efetiva e sobre as alterações inevitáveis devidas às condicionantes do terreno e adaptações da vida urbana.

Em princípio, os projetos seguiam uma normativa restritiva, se não as determinadas em Lei de maneira geral, as determinadas pelos diretores gerais. As terras devolutas destinadas à implantação do núcleo rural, embora definidas por cursos d'água e pela topografia, eram loteadas segundo os parâmetros estabelecidos pela própria Lei de Terras (7), no artigo 14, $\S 1^{\circ}$ : 
Art. 14. Fica o Governo autorizado a vender terras devolutas em hasta publica, ou fóra della, como e quando julgar mais conveniente, fazendo previamente medir, dividir, demarcar e descrever a porção das mesmas terras que houver a ser exposta á venda, guardadas as regras seguintes:

$\S 1^{\circ}$ A medição e divisão serão feitas, quando permittirem as circumstancias locaes, por linhas que corram de norte ao sul, conforme o verdadeiro meridiano, e por outras que as cortem em angulos rectos, de maneira que formem lotes ou quadrados de 500 braças por lados demarcados convenientemente. [...]

De fato, quase um loteamento "de gabinete", os lotes rurais da primeira colônia foram ainda demarcados com lado mínimo de 66 braças $(145 \mathrm{~m})$, de grande profundidade, procurando definir áreas que, na média, se aproximassem da área de um quadrado de 500 braças de lado $\left(121.000 \mathrm{~m}^{2}\right)$. Alguns lotes de exceção foram criados, acrescentando-Ihes frente quando o fundo encontrava os limites da propriedade. Não havia, portanto, qualquer consideração topográfica no sistema de demarcação, exceto dados anteriores da própria terra devoluta. No caso específico de Ribeirão Pires, por se tratar de área montanhosa, as frentes dos lotes foram implantadas voltadas para o único vale que cortava toda a propriedade, estabelecendo-se nele o principal caminho de ligação do núcleo rural com a sede urbana.

Os lotes urbanos seguiam ainda a normativa estabelecida pelos artigos 76 a 79, do Decreto $n^{0} 1318$ de 30 de Janeiro de 1854, que regulamentou a referida Lei de Terras (8):

$[\cdots]$

Art. 77. As terras reservadas pêra fundação das Povoações serão divididas, conforme o Governo julgar conveniente, em lotes urbanos e ruraes, ou somente os primeiros. Estes não serão maiores de 10 braças de frente e 50 de fundo. [...]

Art. 78. Os lotes, em que devem ser divididas as terras destinadas á fundação de Povoações, serão medidos com frente para as ruas, e praças, traçadas com antecedência, dando o Director Geral das Terras Publicas as providencias necessarias para a regularidade, e formosura das Povoações. [...]

No caso de Ribeirão Pires, o núcleo sede foi construído sobre os mesmos padrões de medida e implantação dos lotes rurais. Com lado mínimo de 60 braças (132 m) a 
partir da linha férrea, estabeleceu-se uma retícula que totalizava uma malha de 300 braças $(660 \mathrm{~m})$ de lado. Foram determinadas 5 braças para o arruamento $(12 \mathrm{~m})$. $\mathrm{O}$ decreto, no entanto, acabou sendo interpretado como parâmetro para definição da área do lote urbano, já que se aplicava a valores máximos. O lote de $10 \times 50$ braças (22 $\times 110$ metros) resultava numa área de $2420 \mathrm{~m}^{2}$. Da área resultante loteável de $55 \times 55$ braças (ou $120 \times 120$ metros), determinaram-se 6 lotes de $30 \times 40$ metros cada, com área de $2400 \mathrm{~m}^{2}$. A retícula, ao contrário das colônias rurais, cuja demarcação orientava-se no sentido norte-sul, determinou-se menos pelas necessidades de ordem geográfica e topográfica e mais pelo alinhamento absoluto com a ferrovia.

No entanto, devido às especificidades do terreno e, possivelmente, dos limites da propriedade de D. Maria Florencia Rodrigues - talvez o córrego nos limites do núcleo demarcado -, os lotes fronteiriços foram sempre de exceção, ora adaptandose ao arruamento, ora aos lotes de chácara estabelecidos nas extremidades, com outra normativa, mantendo-se íntegros a essa regra original apenas os quarteirões centrais.

A praça do núcleo urbano e a estrada aberta pelos imigrantes, posteriormente denominada "Estrada da Colônia" do núcleo rural, foram os pontos de contato do sistema ferroviário com esses lotes demarcados.

A primeira, localizada na única área de transição plana entre o vale e o morro destinado ao loteamento, foi estabelecida em perfeita simetria com a estação, o que nos permite inferir quanto à sua importância simbólica para a cidade organizada e planejada, atribuindo o valor de vida urbana que o núcleo sede pretendia oferecer. No seu projeto, a praça foi localizada entre o primeiro e o segundo módulo, racionalmente, segundo modelos ideais do período. Era também o espaço destinado a oferecer os benefícios à comunidade: nela foram construídos um barracão símbolo, ainda que improvisado, do governo enquanto instituição de controle e poder -, a escola - construída poucos meses após a demarcação dos lotes - e a estação - principal e único elo da cidade planejada com o resto do sistema econômico da qual fazia parte. Era também o espaço principal dos lotes "A", destinados a outros edifícios públicos. No entanto, devido à necessidade dos próprios colonos, que lhes 
foi permitido construir uma igreja - homenageando São José. A sua construção acabou por redefinir a praça no alinhamento da rua principal que a ligava à estação.

A estrada, em oposição à primeira, foi estabelecida mais naturalmente, contornando a área de várzea do leito do Ribeirão Grande pelo morro que existia anteriormente na área - demolido junto com as obras de retificação do rio nos anos 1970. De fato, esse morro foi o primeiro lote colonial rural. A estrada, segundo a planta 1:10000, não se direcionava à estação no mesmo ponto que a praça no lote urbano. Ao contrário, encontrava a linha alguns metros abaixo, num encontro possivelmente determinado pelo próprio estacionamento dos vagões de carga na estação. Neste ponto de contato formou-se a atual Rua do Comércio, resultado natural dessa intensa atividade.

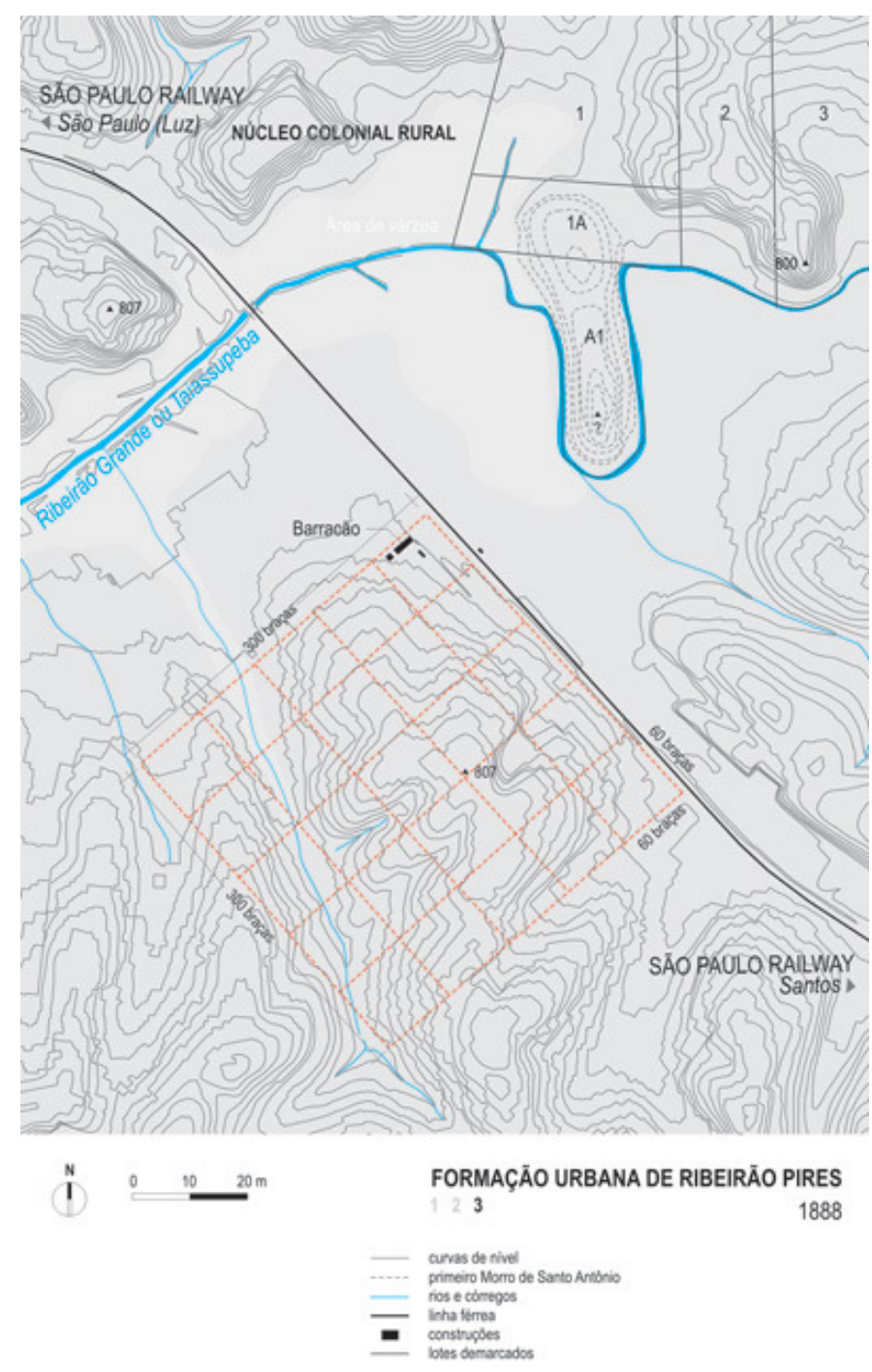

\begin{tabular}{|c|c|}
\hline $\begin{array}{l}\text { FIGURA } 4 \\
\text { elaborado }\end{array}$ & $\begin{array}{l}\text { - Desenho do } \\
\text { a partir de }\end{array}$ \\
\hline $\begin{array}{l}\text { Cartográfica } \\
\text { (FREITAS, } 20\end{array}$ & $\begin{array}{l}\text { da PMETRP, } \\
007 \text {, p. } 30)\end{array}$ \\
\hline
\end{tabular}



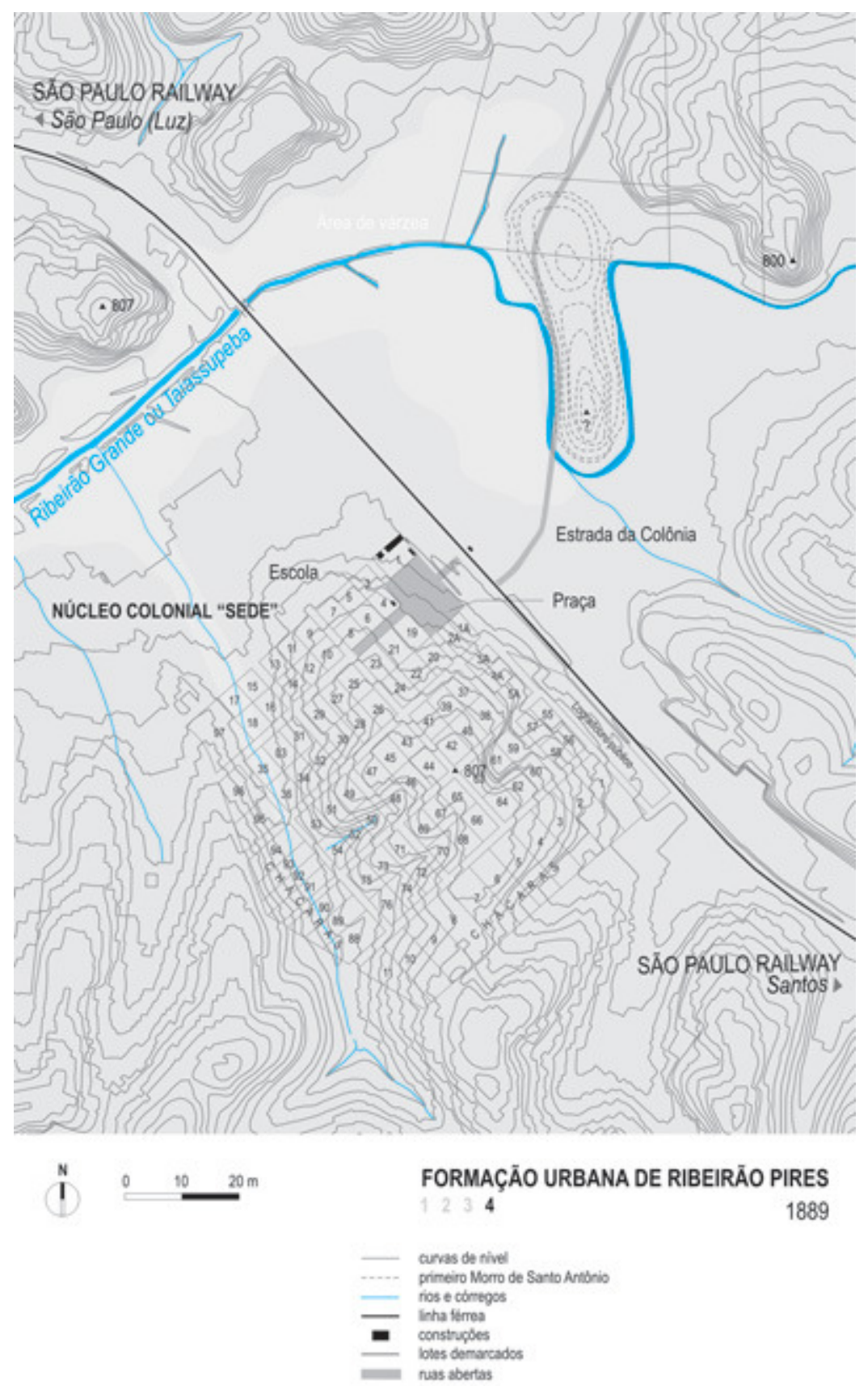

FIGURA 5 - Desenho do autor elaborado a partir de Base Cartográfica da PMETRP, 1997. (FREITAS, 2007, p. 31) 

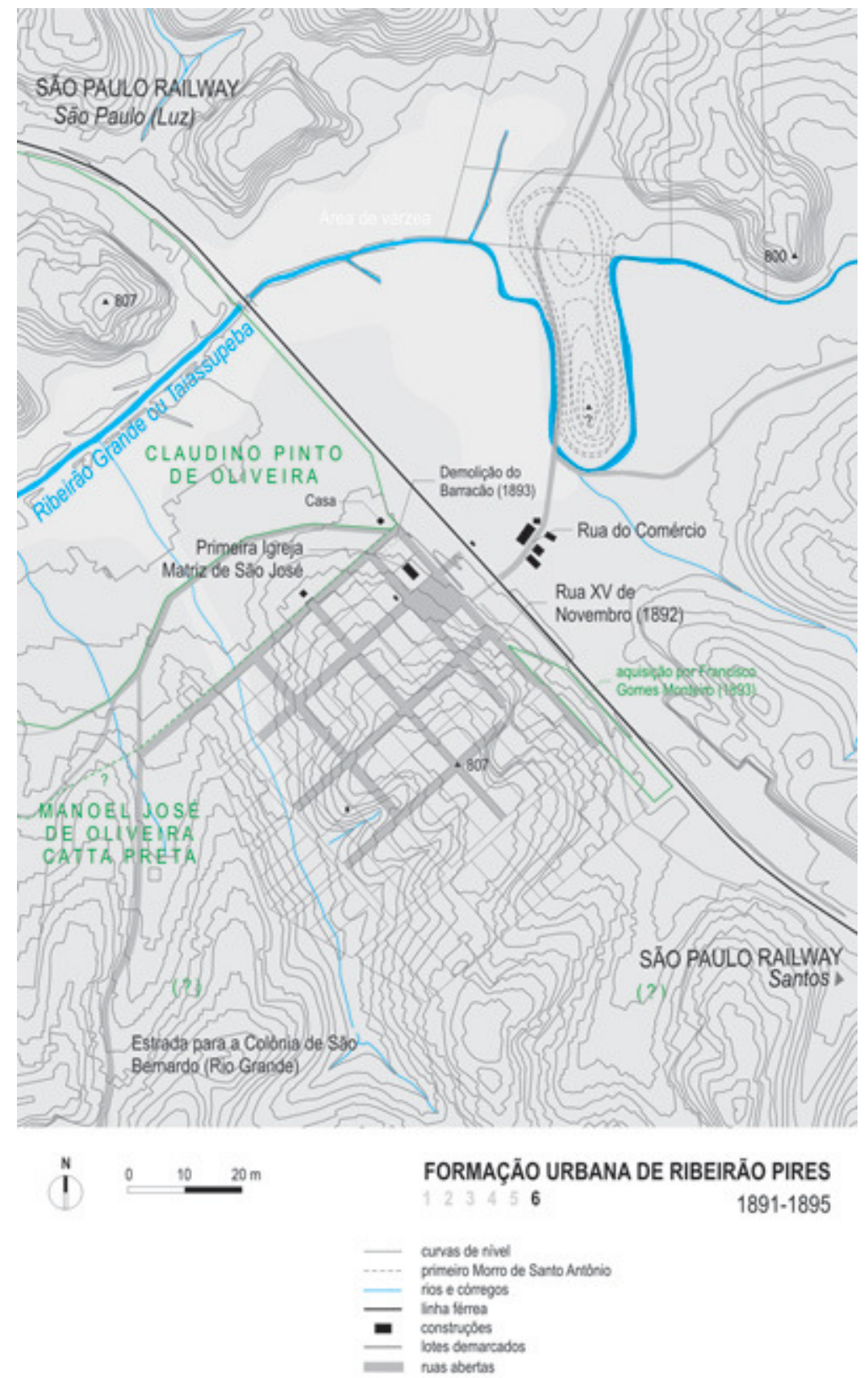

FIGURA 6 - Desenho do autor elaborado a partir de Base Cartográfica da PMETRP, 1997. (FREITAS, 2007, p. 33)

Ao se determinar, portanto, o princípio de uma segunda fase de expansão do sistema ferroviário, descobrimos uma segunda fase da expansão dos núcleos coloniais paulistas. Na primeira etapa de ampliação viária, o núcleo de Ribeirão Pires, pela força desse novo modelo econômico, vinculava-se apenas à ferrovia, então consolidada e plenamente integrada aos processos de produção. Como projeto, fora resultado do aperfeiçoamento gradual do sistema de implantação dos núcleos coloniais do Império e da política econômica que este intentava consolidar, 
estabelecendo-se exclusivamente no contato ferroviário, cada vez mais eficiente pela modernização de sua infra-estrutura e reforçando sua interdependência.

Esses núcleos próximos à capital, inter-relacionados a esse novo tipo de transporte, foram os embriões de um modelo de metropolização das cidades latino-americanas, organizadores de forças centrípetas de expansão e polarizadoras de funções na área central da capital metropolitana (MEYER et al, 2004, p. 35). Na região do entorno da cidade de São Paulo, a conseqüência dada pelo sistema ferroviário foi o reforço da sua hegemonia no território como nó de todo o sistema. Configurou o princípio do denominado "padrão periférico de ocupação" que viria a ter sua ação mais evidente a partir dos anos de 1950. Ao contrário da historiografia sobre o tema, este processo iniciou-se aqui, estabelecendo-se sem rupturas, de um modo contínuo.

No entanto, ainda que representativos de sua consolidação, são também representativos das mudanças iminentes. Apesar de estimulados pelo Império, eram núcleos que não mais se organizavam em função dele. Pelo contrário, eram partes integrantes das forças motrizes do processo que culminaria na dissolução do regime, iniciadas desde os anos de 1880, dando lugar à República em novembro de 1889. Dissociavam-se dele pela sua crescente incompatibilidade política, devido ao mercado que se formava e à necessidade de que a colonização, como um processo vinculado, também estivesse a cargo da "nova economia cafeeira", ou melhor, do "novo capital cafeeiro".

E, de fato, é o que ocorre. Walter Pires indica a euforia do processo de transformação econômica que se deu após o advento da República (PIRES, 2003, p. 60). Estimulada pela política de crédito de Ruy Barbosa, a formação de grandes companhias nos mais diversos ramos, com destaque para aquelas voltadas aos "melhoramentos urbanos" de forte apelo especulativo, exerceram sua pressão econômica para a reorganização fundiária. A necessidade de reaplicação do capital excedente neste cenário transformou claramente as políticas de colonização. Os núcleos coloniais tornaram-se não mais apenas instrumento de fixação dos imigrantes à terra - esta função ainda se manteve obviamente importante -, mas se integraram também eficientemente como meio de circulação do capital. 
Em 1890, as atribuições da "Inspetoria Geral de Terras e Colonisação" são reduzidas, quase extintas. Em seus primeiros anos, o Governo Republicano transfere a responsabilidade de criação de novas colônias e fixação da corrente imigratória, em quase sua totalidade, às companhias privadas ou a indivíduos por concessão. A administração dos núcleos instalados nas províncias desaparelhados desde a centralização dos serviços - levou à rápida emancipação destes e integração quase imediata ao mercado imobiliário. Ainda que os ânimos tenham sido somente resfriados em $1892 \mathrm{com}$ a crise do Encilhamento, resultado dessa euforia que se revelou insustentável, ocorreu um novo direcionamento das políticas de colonização, agora adaptadas a uma economia com forte apelo do mercado imobiliário e do capital industrial.

Em Ribeirão Pires, o núcleo sede naturalmente cedeu à "expectativa urbana" que nele se instalou. São notáveis as ações de personagens como Claudino Pinto de Oliveira e Manoel José de Oliveira Catta Preta, que nos documentos aparecem identificados como agentes da construção da vida urbana do núcleo sede - o primeiro é o construtor da escola, e o segundo solicitante de um lote para a construção de um moinho. Em seguida, porém, ambos aparecem como os grandes proprietários das terras vizinhas, hoje área parcialmente inundada pela Represa Billings.

Somente em 1896, com a contração de um empréstimo na Inglaterra para sanar os problemas de lastro econômico do país iniciou-se, convenientemente, a segunda etapa de modernização da "São Paulo Railway" implicando na reforma completa das estações ferroviárias.

Nesse período, as edificações da linha férrea foram reconstruídas seguindo uma inédita hierarquização e padronização projetual. Suas formas respondiam à função que cumpriam na rede. Nelas foram introduzidas novas técnicas de construção, envolvendo estruturas pré-moldadas de ferro fundido. Cada novo conjunto apresentava, segundo Beatriz Kühl (1998, p. 145) "as características que se tornaram canônicas: [...] edifício retangular de alvenaria de tijolos de um pavimento; abrigo da plataforma sustentado por colunas e consoles de ferro fundido; passarela 
metálica para dar acesso à outra via", sendo acrescentados elementos de acordo com especificidades locais e outras atribuições de projeto ao conjunto.

Dentro desse padrão, concluiu-se completamente a modernização do sistema ferroviário em 1898. A estação de Ribeirão Pires, classificada como de $3^{\underline{a}}$ classe, recebeu assim os elementos "canônicos" acima citados e os demais edifícios sanitários, casa de máquinas, armazém - e um pátio de manobras e estacionamento das composições. Esse conjunto arquitetônico mantém-se íntegro até hoje, assim como as estações de $3^{\text {a }}$ classe similares de Campo Grande, Rio Grande da Serra, Jaraguá, Caieiras, Franco da Rocha e Várzea Paulista que apresentam elementos arquitetônicos idênticos, variando apenas na composição do conjunto (9).

Ribeirão Pires torna-se, portanto, alvo de uma renovação para torná-la mais eficiente às demandas que lhe foram impostas pelo sistema produtivo industrial. Do ponto de vista de projeto, o sistema ferroviário foi revisto e se adaptou à cidade que iniciou seu processo de crescimento à margem do núcleo sede. A estação foi deslocada alguns metros abaixo, devido, supomos, à importância crescente da Estrada da Colônia (e Rua do Comércio), indicando a vocação da cidade para o abastecimento agrícola e industrial rural. No entanto, mesmo com esse deslocamento, a modulação vinculada ao projeto do núcleo sede foi mantida, dessa vez organizando a implantação do próprio sistema. Há ainda uma nova definição do alinhamento da praça com o avanço dos limites dos lotes $1 \mathrm{~A}$ e $2 \mathrm{~A}$ do núcleo sede, permitindo-Ihes, supomos, pelo desenho, também se tornarem as "frentes" mais adequadas do contato do núcleo com a estação, já que a praça - que cumpria esse papel "perdeu" o seu eixo em direção ao vale.

A esse maciço investimento urbano na área, acumulou-se a construção de um moinho de trigo às margens do pátio, em 1898, por uma sociedade de irmãos denominada Fratelli Maciotta que o projetam, na sua lógica fabril, vinculado completamente à linha férrea, estabelecendo-Ihe um ramal próprio e uma plataforma. 

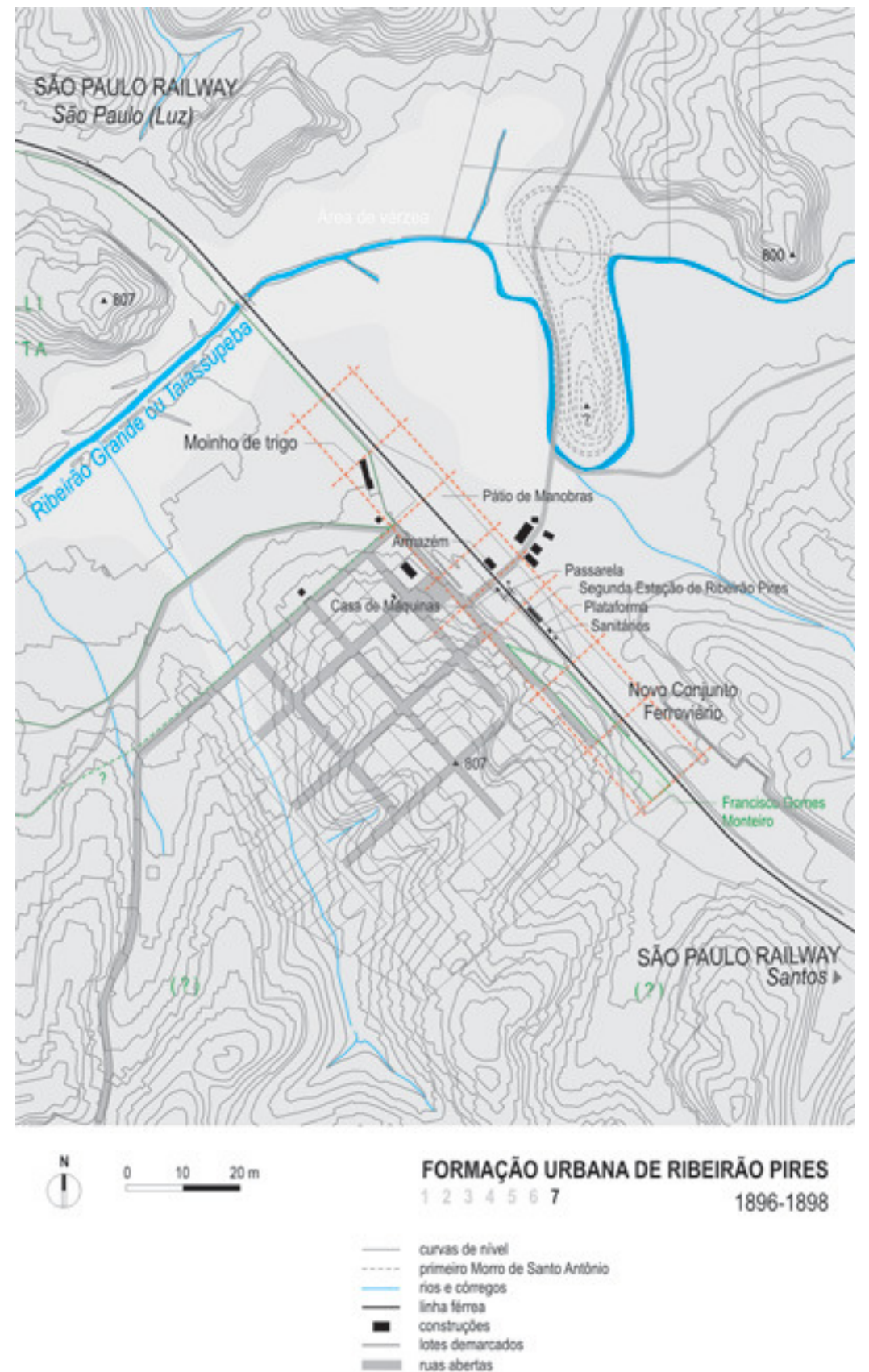

FIGURA 7 - Desenho do autor elaborado a partir de Base Cartográfica da PMETRP, 1997. (FREITAS, 2007, p. 40)

Passados, portanto, 11 anos de implantação do núcleo sede, a cidade readapta os espaços de suas atividades da maneira que melhor lhe convém para cumprir eficientemente seu papel metropolitano. O projeto ideal da praça, ainda que tenha estabelecido grande parte da identidade que existe até hoje ao conjunto do vale, mostrou-se economicamente insuficiente, pelo valor dado à necessidade de construção de uma cidade mais tradicional, ou seja, dinamicamente livre. 
A colônia, no entanto, emancipada pelo estímulo do capital, foi mudando levemente de feição, mas não de função. Sem estabelecer rupturas, suas atividades deixaram de estar ligadas tão fortemente à produção agrícola, adaptando-se definitivamente como um espaço de produção de matéria-prima para as crescentes demandas do mercado paulista, propósito de sua origem. Os ofícios dos imigrantes foram aproveitados e, eles próprios, com a prosperidade gradual do seu trabalho, investem em olarias, pedreiras, serrarias e moinhos, acelerando o processo de instalação de uma pré-industrialização. Abriu-se assim o caminho para a vinculação definitiva da região ao trabalho, à exploração dos recursos naturais, e ao favorecimento da hegemonia da capital sobre os espaços suburbanos.

\section{A continuidade do processo de industrialização: o sistema econômico fundamenta a formação de uma identidade urbana}

Se até o momento foi possível perceber as tentativas de construção de uma cidade dimensionada por uma política colonial que acabou não se mostrando plenamente eficiente, a partir de sua dissolução ela passou a evoluir. As alterações urbanas determinadas pela construção do conjunto ferroviário irradiaram-se na definição de novos espaços de ocupação nos ambientes ainda não plenamente carregados de uma certa urbanidade - ou seja, o vale, as estradas, as terras vizinhas ainda não loteadas - mas caracterizados por uma imensa potencialidade para receber esse crescimento. $\mathrm{O}$ avanço da formação de uma cidade mais tradicional determinou $\mathrm{O}$ modo de expansão urbana de Ribeirão Pires na primeira metade do século $X X$, apropriando-se do sistema econômico implantado e dando-Ihe força.

O vale central de Ribeirão Pires, na primeira metade do século $X X$, passou a ser um espaço definido pela constante articulação econômica entre os resultados da implantação da cidade ideal - o núcleo sede, que ocupa a colina a sudoeste -, e o desenvolvimento da cidade tradicional - que se estabeleceu no vale, tanto à margem do núcleo sede como também no outro lado da linha férrea. De um lado, situou-se o núcleo já implantado como a representação coletiva da imagem de Ribeirão Pires; do outro, desenvolveu-se um espaço definido pela produção destinada ao abastecimento de mercados externos baseado em meios de produção pré-industriais. Se, na primeira "cidade", sua origem esteve relacionada a um procedimento econômico racionalizado - ou seja, o projeto - que qualificou o caráter 
da cidade no período, por outro, na segunda, definiu-se de maneira empírica, numa resposta também lógica às mesmas necessidades da cidade ideal. Ao mesmo tempo, esses padrões de construção permitiram a delimitação de dois aspectos fundamentais de Ribeirão Pires: de um lado da linha férrea formou-se definitivamente uma cidade institucional e, do outro, uma cidade industrial e comercial, determinando a construção da vida urbana do vale que a caracteriza até hoje.
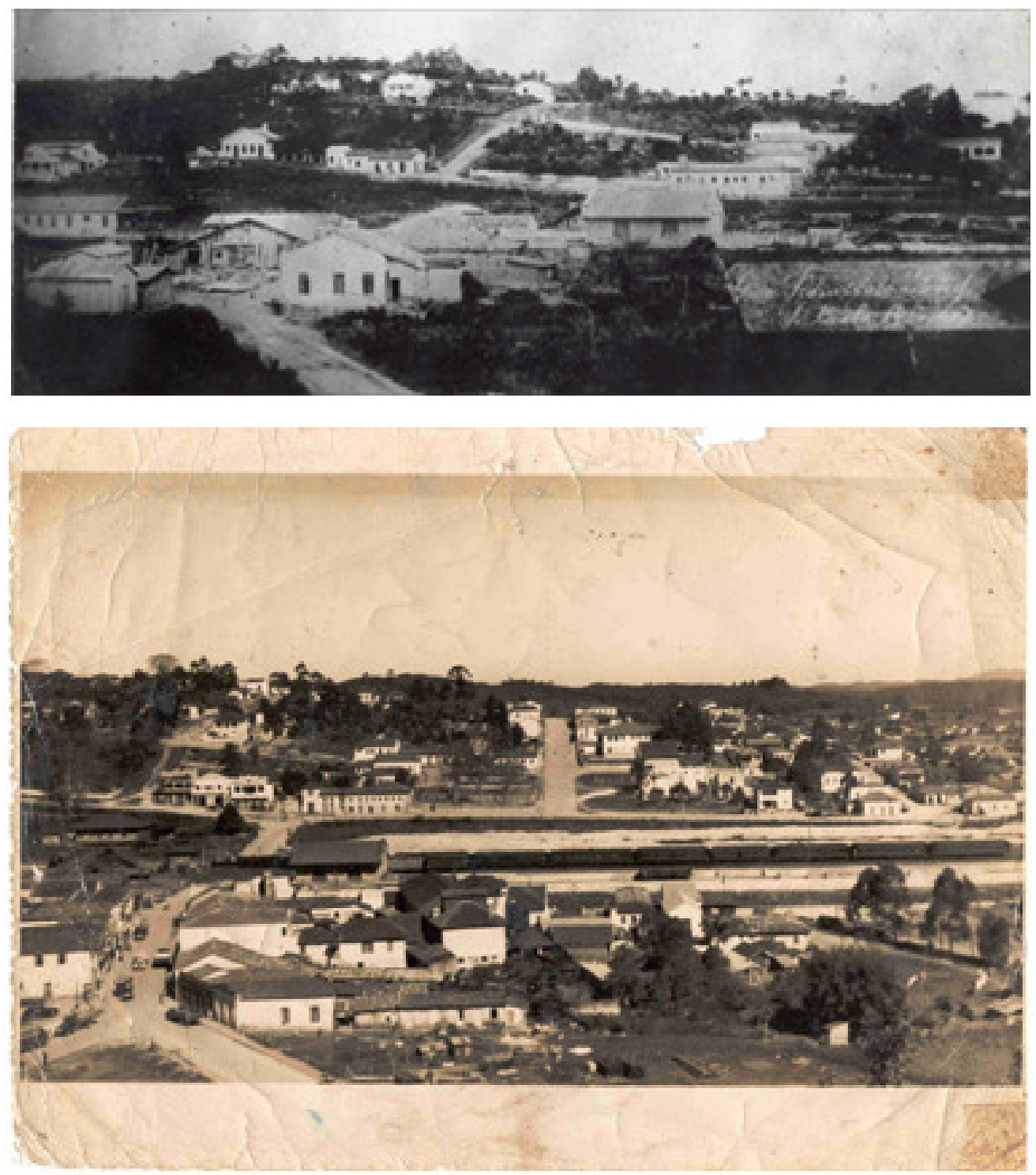

FIGURA 8 - Acima, fotografia datada [190-], primeira década do século XX, indicando em primeiro plano a Estrada da Colônia e a Rua do Comércio em formação. Ao fundo, parte do novo conjunto ferroviário e a paisagem do núcleo "Sede". Abaixo, fotografia provavelmente dos anos 40 , em ângulo similar, em que se nota as "duas" cidades unidas visualmente pelo vazio do conjunto ferroviário. Fonte: CATP/PMETRP. 
Desse modo, se a linha férrea, desde a origem, pode ser considerada a matriz urbana que caracterizou formalmente essas "duas" cidades, é na estação que ocorre o principal (e único) ponto de união. Se antes a vinculação do desenho do projeto urbano do núcleo sede já se relacionava à ferrovia, agora, esse verdadeiro "monopólio" urbano atribuído ao papel da estação enquanto articulação urbana demonstra finalmente a sua importância, também, para a cidade que se desenvolve mais tradicionalmente. De fato, a nova estação ferroviária adquiriu uma presença enorme na paisagem urbana, fundamentando o princípio de que qualquer alteração de sua dinâmica representava também a alteração da própria dinâmica urbana como um todo, além de reforçar o fato de que essas "duas" cidades não são opostas, mas sim, complementares a partir do eixo ferroviário. A Praça XV de Novembro do núcleo colonial "Sede" (agora da Matriz) continuou a tecer as suas influências na vida coletiva - mesmo tendo perdido uma imediata relação com o desenho urbano que a caracterizou. Ao mesmo tempo, a Rua do Comércio passou a representar um ícone da atividade econômica da cidade.
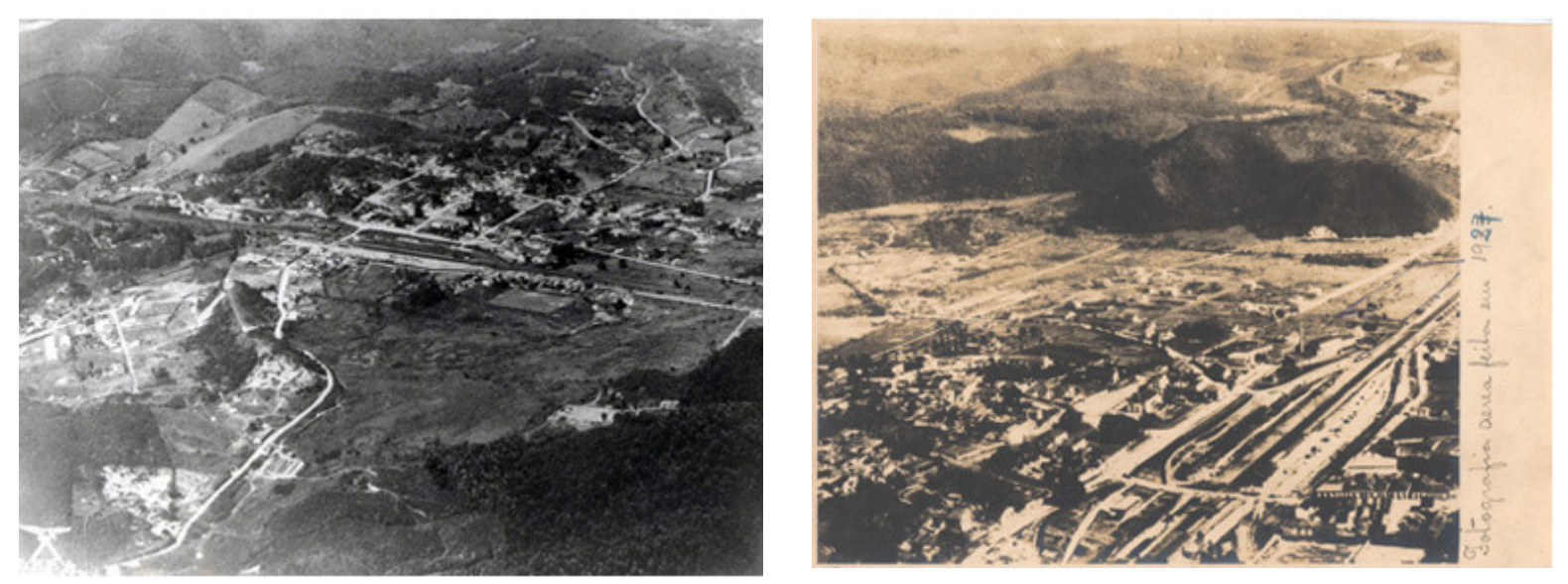

FIGURA 9 - Acima, fotografia aérea de Ribeirão Pires, anos 30. Em primeiro plano, a Estrada da Colônia e, ao fundo, o núcleo colonial "Sede" e o conjunto ferroviário. Abaixo, Fotografia aérea de Ribeirão Pires, provavelmente tirada nos anos de 1920 ou de 1930. Note-se a imprecisão em relação ao ano de produção da fotografia sugerida pela sobreposição das datas 1933/1927. Em outro ângulo de visão, em primeiro plano, a linha férrea, o conjunto ferroviário e a Rua do Comércio. Ao fundo, área do Ribeirão Grande que será posteriormente alagado pela Represa Billings. Fonte: CATP/PMETRP.

Devido à presença das construções já implantadas, à garantia de visualidade no vale pelo vazio ferroviário, e, sobretudo, à força de sua representatividade, a 
importância da Praça na cidade permanece, já que continua sendo o espaço da igreja e da escola. Não apenas confere uma necessária presença urbana de valores institucionais, como também define o princípio de um certo grau de historicidade ao conjunto.

Com esse mesmo sentido polarizador, a Rua do Comércio permitiu a criação de um novo espaço que concentrou as atividades que a Praça deixou de suprir. Como o próprio nome the atribuiu, uma rua de atividade comercial e espaço da atividade econômica propriamente dita. Trata-se, portanto, de um novo centro, um novo pólo. Pelas características do local em que se implanta - as proximidades com a várzea do Ribeirão Grande e a presença do morro - a sensação urbana além desses elementos é a de deixar o vale, deixar esse "contato", um dos motivos que, supomos, inviabilizou seu crescimento ao longo da Estrada da Colônia.

Ao mesmo tempo, por esses motivos, o morro tornou-se também importante na cidade tradicional, pois é a partir dele que duas situações acontecem. A primeira, já relatada, é a de que ele é um obstáculo e, portanto, enquanto tal, o desenho que criou a estrada que o margeia já se adaptara em função dele. A segunda é a possibilidade de que ele se constituiu num mirante, permitindo à população "ver" totalmente a cidade que se desenvolve e, a partir dele, portanto, atribuir a identidade que fundamenta o seu próprio crescimento. As ruas do núcleo colonial sede e as novas construções ferroviárias ligadas a esse novo centro urbano tornam-se paisagem visível e, enquanto tal, permitem o reforço tanto do avanço desta cidade como do próprio sistema econômico. A prova dessa função é a referência a uma Igreja, consagrada a Santo Antônio, erigida sobre o morro, que assim passou também a se denominar. 

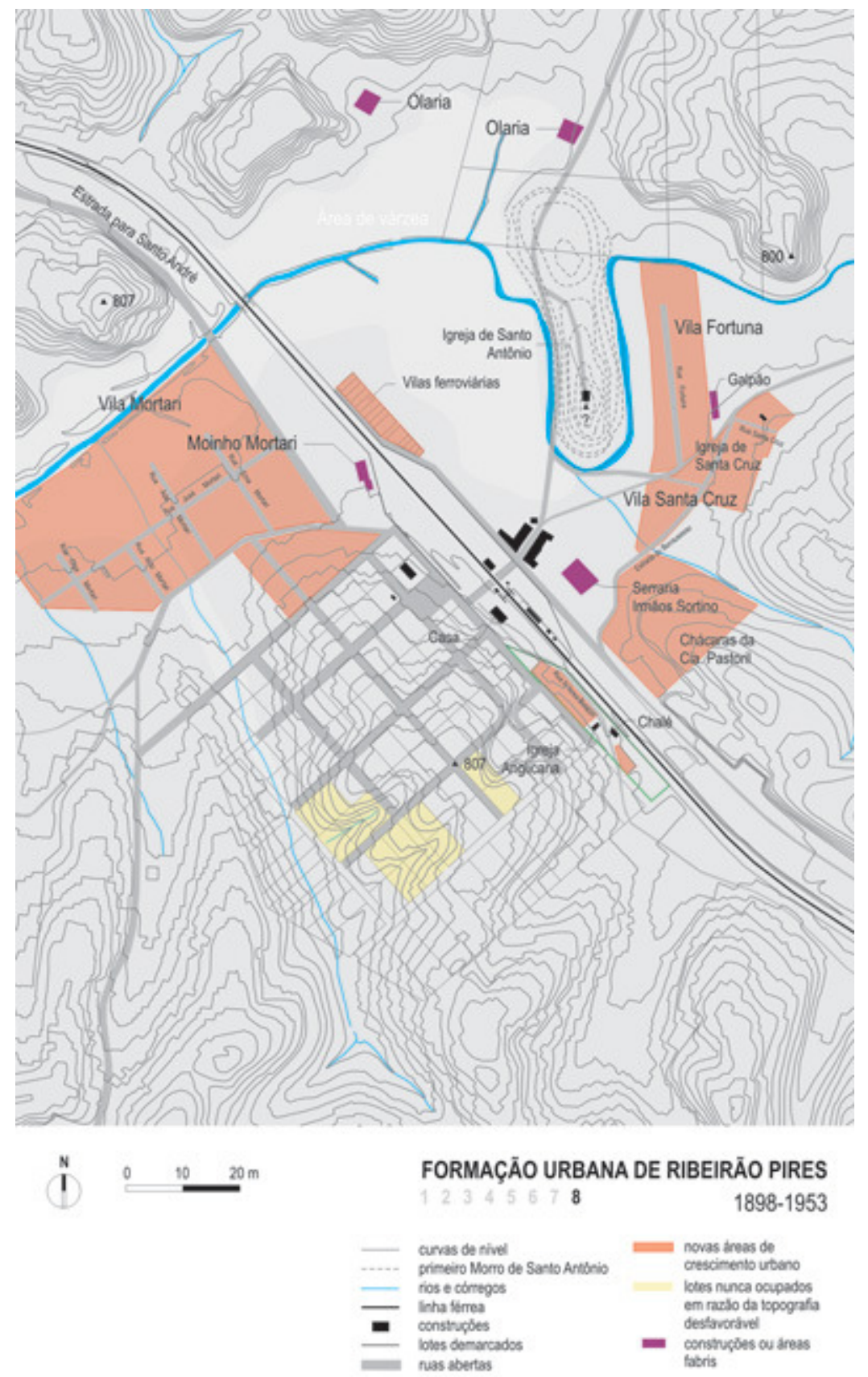

FIGURA 10 - Desenho do autor elaborado a partir de Base Cartográfica da PMETRP, 1997. (FREITAS, 2007, p. 46)

Desse modo, enquanto pólo, as construções na Rua do Comércio cumprem o papel de estabelecer o contato com o sistema ferroviário, traduzindo-se no elemento necessário à construção de uma cidade que se vincula totalmente à industrialização. Ou seja, não se trata apenas de um espaço gerado pela casualidade da passagem sim, ela também é isso -, mas obviamente de um espaço que concentra o destino da produção industrial que se formou no seu entorno. Trata-se, portanto, de um espaço concebido com uma função clara, estabelecendo a continuidade do sistema produtivo. 
$E$, de fato, a cidade tradicional do início do século XX em São Paulo é, por excelência, a cidade que se organiza em função da manufatura, atribuindo aos espaços os primeiros vínculos de uma formação pré-industrial. E, do mesmo modo, os espaços fabris geraram novas concentrações.

Os empreendimentos que acabaram se destacando foram aqueles que se relacionavam diretamente com estes espaços, resultado deles. A Vila Mortari, por exemplo, é o resultado de um loteamento implantado à margem do Moinho Mortari (ex-moinho Fratelli Maciotta), nos anos de 1920, que cresce em produção e em tamanho, quando Ihe são acrescentados novos galpões de alvenaria. As habitações, até hoje presentes, respeitam o padrão tipológico vigente no período: casas geminadas em sua grande maioria com recuos e varandas laterais. A serraria Irmãos Sortino, situada em frente à saída da estação (num ponto atualmente ocupado pela rodoviária), irradia o desenvolvimento dos bairros de Santa Cruz e Vila Fortuna, também estimulados pelas diversas olarias existentes na região do Barro Branco, em área mais afastada. E, também, a própria "São Paulo Railway" constrói algumas casas destinadas a funcionários e operários, hoje parcialmente abandonadas, mas que ainda apresentam os indícios de terem pertencido ao sistema ferroviário.

Nos núcleos coloniais, pelo enxugamento da área necessária à produção, os extensos lotes do núcleo "Colônia" e "Pilar" são fracionados, evidenciando algum impulso determinado pela deficiência destes enquanto sistema de ocupação. Quando a topografia permite, pequenas vilas de casas são formadas, respeitando os limites da demarcação anteriores, o que nos leva a supor que se tratava de empreendimentos dos próprios ocupantes obedecendo a uma clara demanda. Ao mesmo tempo, houve lotes demarcados que nunca chegaram a ser ocupados, tanto pela dificuldade da construção em topografia íngreme e má insolação, como pela própria distância com o centro urbano, caso de boa parte da colônia "Pilar". (ver figura 3). No núcleo colonial "Sede", portanto, ocorre o mesmo procedimento, já que se integra a essa dinâmica. 
A ferrovia nunca se apresentou como um elemento desintegrador do vale. Pelo contrário, seu aspecto de unidade é valorizado tanto pelo eixo da Rua do Comércio como pelo vazio que ele gera nessa área central, permitindo que cada lado da cidade possa ser visto. Assim, com uma base projetual lançada e um claro sistema de produção definido, os processos de identificação da população com o lugar em que trabalham e ocupam começaram a agir efetivamente pela atividade cotidiana. A população finalmente começou a atribuir significado aos espaços da vida coletiva sugeridos pelo plano inicial, construindo uma gradual imagem de si própria neste espaço totalmente novo.

\section{Considerações finais}

Fica evidente, desse modo, que a atribuição hoje da história do município como um lugar denominado Ribeirão Pires à Igreja do Pilar é totalmente descabida. Embora seja aquilo que o município "possua" de mais antigo, a cidade não pode vincular seu passado à uma construção cujo entorno urbano, de fato, não existe. Mesmo porque essa justificativa, no campo da preservação, está superada há muito tempo. No entanto, o valor da Igreja do Pilar é inegável, desde que seja equilibrado e não se sobreponha à verdadeira formação da cidade enquanto um ícone simplesmente. Este conceito é prejudicial, inclusive, para a própria Igreja, já que pode limitar também o campo de entendimento da formação do território do atual Grande ABC, anterior ao processo de industrialização no final do século XIX.

Assim, essa pesquisa tem a função de se estender enquanto método. A partir de um problema de percepção, buscou-se uma possibilidade de estudo que permitisse a valorização das nossas cidades com outros olhos. Isto porque a necessidade de revisão dos parâmetros de intervenção nas cidades contemporâneas, antes de qualquer pensamento, é iminente. A História (e a memória) não é uma referência do que foi, mas sobretudo a possibilidade de estudo daquilo que pode vir a ser através da nossa ação responsável sobre o presente.

Quando, portanto, os parâmetros que guiam as políticas públicas municipais de intervenção puderem se voltar exclusivamente para o estudo sistemático de si próprias, seu valor intrínseco poderá ser recuperado, visto que, no caso de Ribeirão Pires, embora seus indícios físicos permaneçam ignorados, diferentemente de 
muitas cidades, ainda não se perderam. Trata-se de um novo reconhecimento, de um novo processo urbano que seja capaz de atribuir novas identidades sem falsear o mais importante, sua essência.

Procura-se, assim, através da História, por uma metodologia de projeto de intervenção urbana que se vincule não a premissas e preconceitos de ordem pessoal, mas a um comprometimento com as próprias cidades, apontando seu valor pelo estudo e compreensão de sua gênese, e desconstruindo hábitos mentais de percepção do espaço e da história. Isto, com o fim de apresentar, possibilitar e conjugar novos parâmetros que possam alterar o atual modo de transformação das cidades contemporâneas pelo correto entendimento de suas referências, manifestando-se contra a uniformização das identidades urbanas promovidas pelos seus agentes públicos.

Assim, a busca pela preservação do patrimônio construído como modo de reavaliar a cidade que se constrói no presente, ou seja, como um processo político, pode, portanto, ser uma saída para a recuperação dessas identidades. No caso de Ribeirão Pires, o turismo, uma legítima vontade de buscar um novo padrão econômico não é capaz de, sozinho, assumir a condição que promete. Para isso, ele deve vir acompanhado de um novo estudo sobre a cidade e novas propostas urbanas que tenham qualidade e sustentabilidade, com o fim de restabelecer coesão e sentido, tanto material como simbolicamente.

Fundamentalmente, uma cidade que pretende atingir esses atributos deve começar de dentro para fora, deve começar a valorizar seus espaços de modo que a própria população de sinta à vontade para utilizá-los e, por fim, exibi-los por sua verdade memorial que sempre assumiram. Se não for para isso, para que serve então a arquitetura que produzimos em nossas cidades?

\section{Notas}

Este artigo é baseado em um fragmento do Trabalho Final de Graduação (TFG), defendido pelo autor à FAUUSP, em 2006, sob o título "Formação e Transformação Urbana de Ribeirão Pires: em busca de um método de intervenção na cidade contemporânea”, orientado pela Profa. Dra. Beatriz Piccolotto Siqueira Bueno. 
(1) Lei ํㅜ 601, de 18 de sSetembro de 1850.

(2) Vejo como oportuna a reprodução da argumentação de José Luiz Cavalcante: "Em pouco mais de vinte artigos, a Lei de Terras de 1850 tentou corrigir os erros cometidos pelo Brasil durante o período colonial (nas concessões de sesmarias) e início da independência até sua promulgação (o crescimento do número de posseiros) e, dentro das possibilidades, promover a imigração a fim de substituir o trabalho escravo." (CAVALCANTE, 2005, n. p.)

(3) Art. 10: "Ficam proibidas as aquisições de terras devolutas por outro título que não seja o de compra. [...]"

(4) Decreto ํㅜ 6129, de 23 de fevereiro de 1876.

(5) Sobre o Núcleo Colonial de São Caetano, José de Souza Martins apresenta um extenso trabalho de reconhecimento das ruas determinadas em função desses antigos caminhos coloniais e da lógica que estimulou a implantação dos núcleos coloniais nesta primeira fase. (MARTINS, 2000, p. 119-174)

(6) Foi consultado, para este trabalho, um dossiê de levantamento e transcrição dos documentos sobre Ribeirão Pires no Arquivo do Estado, elaborado por estagiários em História do CATP, de 2000 a 2004, disponível no mesmo departamento da Prefeitura Municipal.

(7) Lei ํㅜ 601, de 18 de setembro de 1850.

(8) Idem.

(9) Não foi possível, no entanto, para a elaboração deste trabalho, levantar mais dados sobre o uso desses edifícios, como por exemplo, se a casa de máquinas ainda é usada para o controle do sistema de trens, se "a casa do chefe da estação", integrada ao pavilhão de alvenaria da plataforma, ainda se mantém internamente intacta ou, até mesmo, se essa figura profissional ainda existe, visto que se tratam componentes de um programa arquitetônico concebido com outra lógica que não é a da readaptação de uso ao sistema de trens suburbanos da CPTM. De todo modo, a presença do conjunto na paisagem, foco deste trabalho, ainda persiste.

\section{Referências Bibliográficas}

AURÉLIO, Cláudio; SCALABRINI, Marina. Patrimônio e cidade: "sobrevivências" do passado em Ribeirão Pires. [S.I.]: Vitruvius, 2004. Disponível em: <http://www.vitruvius.com.br/arquitextos/ arq000/esp233.asp>. Acesso em: 20 jul. 2006.

CAVALCANTE, José Luiz. A Lei de Terras de 1850 e a reafirmação do poder básico do Estado sobre a terra. Histórica: Revista online do Arquivo Público do Estado de São Paulo, n. 2, jun. 2005. Disponível em: <http://www.historica.arquivoestado.sp.gov.br/materias/anteriores/edicao02/materia02>. Acesso em: 1 dez. 2006.

CYRINO, Fábio Rogério Pedro. Café, ferro e argila: a história da implantação e consolidação da empresa The San Paulo (Brazilian) Railway Company Ltd. por intermédio da análise de sua arquitetura. Dissertação (Mestrado)-Faculdade de Arquitetura e Urbanismo da Universidade de São Paulo (FAUUSP), São Paulo, 2000. 
FREITAS, Pedro Murilo G. Formação e transformação urbana de Ribeirão Pires: em busca de um método de intervenção na cidade contemporânea. Trabalho de Conclusão de Curso (Graduação)-Faculdade de Arquitetura e Urbanismo da Universidade de São Paulo (FAUUSP), São Paulo, 2007. Orientado por Beatriz Piccolotto Siqueira Bueno.

KÜHL, Beatriz Mugayar. Arquitetura do ferro e arquitetura ferroviária em São Paulo: reflexões sobre a sua preservação. São Paulo: Ateliê Editorial, 1998.

MARTINS, José de Souza. Subúrbio - vida cotidiana e história do subúrbio da cidade de São Paulo: São Caetano do fim do Império ao fim da República Velha. 2. ed. São Paulo: Hucitec; Unesp, 2002.

MENESES, Ulpiano T. Bezerra de. Patrimônio ambiental urbano: do lugar comum ao lugar de todos. CJ Arquitetura, n. 19, 1978.

MEYER, Regina. Metrópole e urbanismo: São Paulo Anos 50. Tese (Doutorado)-Faculdade de Arquitetura e Urbanismo da Universidade de São Paulo (FAUUSP), São Paulo, 1991.

MEYER, Regina; GROSTEIN, Marta Dora; BIDERMAN, Ciro. São Paulo Metrópole. São Paulo: EDUSP; Imprensa Oficial do Estado de São Paulo, 2004.

PEREIRA, Eduardo Carlos; FILIPPINI, Elisabeth. Cem anos de imigração italiana em Jundiaí. São Paulo: Estúdio $\mathrm{RO}, 1988$.

PIRES, Walter. Configuração territorial, urbanização e patrimônio: Colônia da Gloria (1876-1904). Dissertação (Mestrado)-Faculdade de Arquitetura e Urbanismo da Universidade de São Paulo (FAUUSP), São Paulo, 2003.

RELATÓRIOS apresentados pela Secretaria de Estado dos Negócios da Agricultura, Comércio e Obras do Império nos anos de 1874, 1886, 1887 e 1888, e da República nos anos 1889, 1890 e 1891. Disponível em: <http://brazil.crl.edu/bsd/bsd/hartness/agricultura.html>. Acesso em: 1 dez. 2006.

RELATÓRIOS apresentados pelo Ministério da Indústria, Viação e Obras Públicas da República nos anos de 1892, 1893, 1894, 1895, 1896, 1897 e 1898. Disponível em:

<http://brazil.crl.edu/bsd/bsd/hartness/agricultura.html>. Acesso em: 1 dez. 2006.

RELATÓRIOS apresentados à Assembléia Legislativa Provincial de S. Paulo pelos Presidentes da Província nos anos de 1887, 1888, 1889, 1890, 1891 e 1892. Disponível em: <http:/www.crl.edu/content/brazil/sao.html>. Acesso em: 1 dez. 2006.

\section{Arquivos}

Arquivo do Estado de São Paulo.

Centro de Apoio Técnico ao Patrimônio (CATP), Prefeitura Municipal da Estância Turística de Ribeirão Pires (PMETRP).

* Arquiteto formado pela FAU-USP. Pós-graduando em Teoria e Prática do Restauro do Patrimônio Arquitetônico e Urbanístico pela UNISANTOS.

e-mail: pmugf.arq@gmail.com 